\title{
Creative Digital Marketing and Advanced Internetworking Assistance Programs for Micro, Small and Medium Enterprises in Buah Batu District Bandung
}

\author{
Bethani Suryawardani ${ }^{1}$, Astri Wulandari ${ }^{1}$, Gandeva Bayu Satrya ${ }^{1}$, Rahmadi \\ Wijaya', Wahyu Lukito², Bijaksana Prabawa ${ }^{2}$, Dandy Marcelino ${ }^{3}$ \\ ${ }^{1}$ School of Applied Science, Telkom University; \\ ${ }^{2}$ School of Creative Industry, Telkom University; \\ ${ }^{3}$ School of Economy and Business, Telkom University \\ E-mail: bethani@tass.telkomuniversity.ac.id, astri.wulandari@tass.telkomuniversity.ac.id, \\ gbs@telkomuniversity.ac.id, rahmadi@tass.telkomuniversity.ac.id, \\ wahyulukito@telkomuniversity.ac.id, bijaksanaprabawa@gmail.com, dandy.marcel@gmail.com
}

Article History:

Received: July $10^{\text {th }} 2020$

Revised: Aug 2nd 2021

Accepted: Nov 31 2021

Keywords: Creative Digital Marketing, Advanced Internetworking, Competitive Advantages, Service Learning

\begin{abstract}
Digital media can support Micro, Small, and Medium Enterprise (MSME) businesses to increase brand awareness of their products, so they can gain competitive advantages and reach a broader market. Unfortunately, not all MSME businesses have the capabilities to utilize digital media to support their businesses. The MSMEs in Buah Batu district face problems that can not be resolved by conventional marketing methods, such as lack of brand awareness and drop in sales which results in the decrease of their revenues and profits. This Community Service aims to improve the MSME's knowledge and skills on creative digital marketing strategy and their understanding of the marketplace so they can create online stores for their businesses. Online stores make it feasible for those MSMEs to broaden their market reach. For the problems related to the IT area, the team will provide network training. The method applied was the service-learning approach. The results of this community service are that the MSMEs in Buah Batu District are capable to create their online shops, promote their products through the marketplace and social media and finally increase their revenues. The output of these community service activities is the design of MSME product packaging and website.
\end{abstract}




\section{Introduction}

Information and communication technology is currently growing rapidly, almost all activities of all age categories cannot be separated from internet access. With limited time, the practicality of the internet makes it easier for consumers to find various products and services they need by using the internet. ${ }^{1}$ Therefore, every Micro, Small and Medium Enterprise doers need to take advantage of this digital media to increase brand awareness of their products, so that the products and services could have high competitive advantages and compete amid increasingly fierce market competition. ${ }^{2}$

Buah Batu District is a work unit functioning in the fields of government, business and development, education and society, as well as security and order. Buah Batu District is divided into four sub-districts or villages, namely: Margasari, Cijawura, Sekejati, and Jatisari. Those four sub-districts have a total of 373 RT and 55 RW spread across Buah Batu District. The vision of Buah Batu District is " Terwujudnya Kecamatan Buah Batu Yang Siap Pisan ". The words "Siap Pisan" stand for synergistic, innovative, accountable, professional, pinunjul, healthy, religious tur nanjeur. The meaning and importance of Buah Batu District's vision is the realization of the government administration in the district. The functions and roles of district institutions in the implementation of public services are based on community satisfaction and the principles of good governance, good excellence, and good services.

Buah Batu District has a large potential of micro, small and medium enterprises (MSMEs). According to the data obtained, there are 189 MSMEs with 3 product categories, namely goods, services, and processed products. The MSMEs in Buah Batu District distributes 4 villages: Sekejati has 23 MSMEs; Margasari has 55 MSMEs; Cijawura has 15 MSMEs; and Jatisari has 96 MSMEs. The products in Buah Batu District are diverse, ranging from culinary, convection, consulting services (IT), construction services, travel agents, shipping, as well as varieties of high-quality handicrafts such as knitwear, painted clothes, organic soap and recycled products. The citizens of Buah Batu are experts in creating works that provide the economic potential for families. Figure 1 is the map of Buah Batu District.

${ }^{1}$ Zain, Nuryetty, and Susan Febriantina. "Sosialisasi Kewirausahaan dan Pendidikan Anak; Antara Bisnis On Line dan Mengasuh di Era Digital." Jurnal Pemberdayaan Masyarakat Madani (JPMM) 1.2 (2017): 267-279.

2 Vernia, Dellia Mila. "Peranan Pendidikan dan Pelatihan Media Sosial dalam Pemasaran Online untuk Meningkatkan Daya Saing Usaha Mikro Kecil Menengah (UMKM)." Lectura: Jurnal Pendidikan 8.2 (2017). 


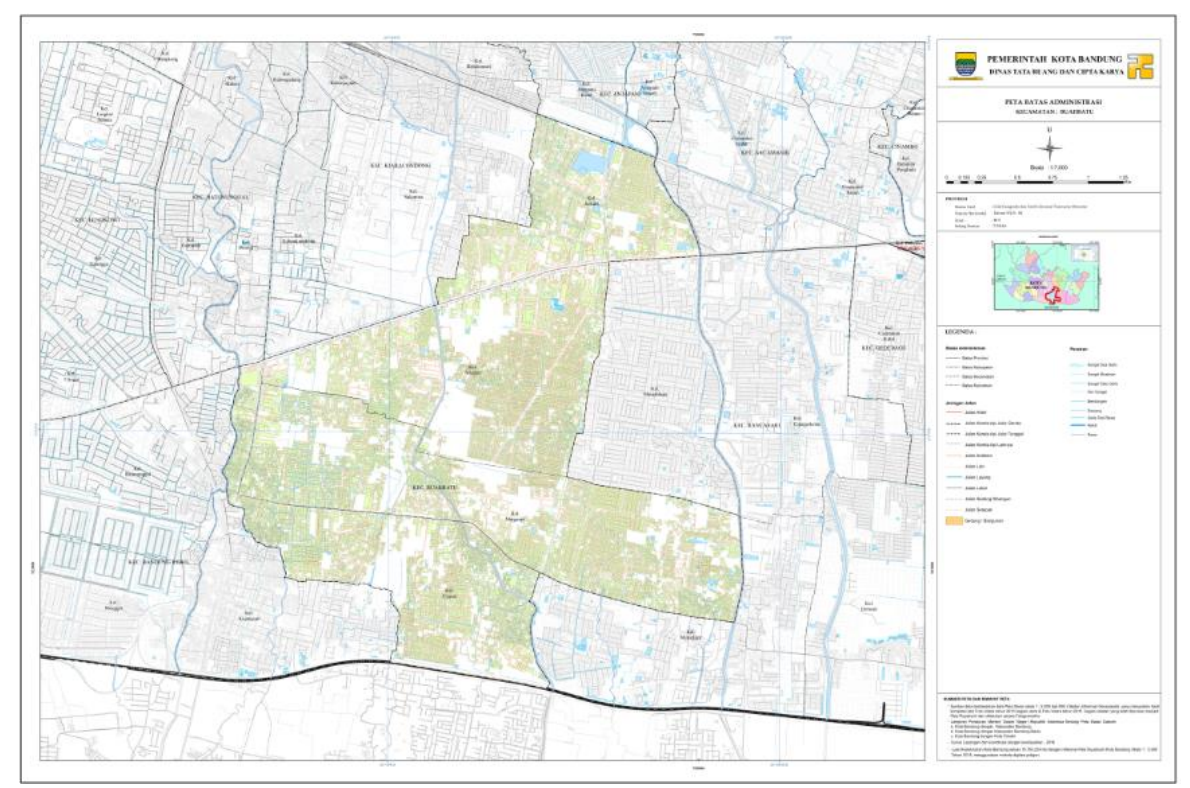

Figure 1. Map of Buah Batu District

Buah Batu District has been organizing various coaching and training by optimizing social institutions, encouraging its citizens to be independent in entrepreneurship. One of the efforts that has been made by Buah Batu District in fostering MSMEs is through continuous guidance from the Division of Economics and Development (EkBang) to improve their product quality and performance. Buah Batu District strives to optimize the capacity of its micro, small and medium enterprises (MSMEs) by collaborating with academics from various universities to add insight, skills, and expertise to MSME actors in running their business. This is intended so that MSME actors can be more independent in developing their business and broaden their market to other cities and abroad.

Based on the interviews with Camat Secretary as a representative of Buah Batu District, there are several problems faced by MSMEs in Buah Batu District which will become the issues and focuses of this community service: (1) Marketing and promotion activities carried out by Micro and Small Enterprises in Buah Batu District are still using the conventional method. (2) Product design and packaging from MSMEs in Buah Batu District has not met the standard. (3) The website of Buah Batu District has not been integrated with several supporting applications such as population applications, Disdukcapil, online complaint services, social media, etc. (4) There are several computer network problems around Buah Vatu District, especially in their Service Offices. (5) The database owned by Buah Batu District has not been integrated with several population applications and websites and cannot be automatically updated. (6) The statistic of population, data and information of product types and MSME are not complete and updated. (7) There is no website containing profiles of superior products from Buah Batu District that can increase brand equity and competitive advantages of their MSME products. 
The MSME products in Buah Batu District consist of various types of products that have the potential to be used as an attraction for local and foreign tourists visiting the city of Bandung. However, based on the team's observations, the MSME products have not met the product standards to be able to compete with similar products, whether from its quality, labeling, packaging, or product design. So, one of the initiatives in this community service is to provide workshops for MSME actors to enhance their knowledge and capabilities to produce products with higher value and are able to compete with similar products.

Websites hold a critical role in today's digital era. The public can easily access all information they needed through websites. ${ }^{3}$ The interview with representatives from Buah Batu District revealed that the website in Buah Batu District had not been integrated with its supporting applications, so users who need certain information have to open several websites and applications which is considered difficult and ineffective. To overcome this problem, the team will integrate the related applications and websites to Buah Batu District's website to make it easier for the users accessing the website. In addition, the team also provides assistance in database system management to facilitate maintenance and further development. Regarding network problems, the team conducts training on how to maintain and configure the network to make it more optimal. The assistance and training related to IT are intended for IT staff in Buah Batu District. Building an integrated website can give its users more effective and efficient access.

From the various problems described previously and as expected social changes, the team tries to provide assistance in workshop creative digital marketing strategy for MSMEs, create websites profiling their superior products, integrate the websites with supporting applications that make it easier for users and create reliable and updated database systems. Based on the interview results, representatives of MSMEs in Buah Batu District suggest that assistance programs for MSMEs are needed such as workshops in digital marketing strategies to be implemented in their respective businesses. They also need to increase and change their marketing mix, which consists of product, price, place, distribution, and promotion from conventional media to digital media. ${ }^{4}$ The benefits that will be obtained from the MSME product website are high credibility, product and brand development, online marketing assisted by Search Engine Optimization (SEO) which can increase the brand equity of MSME products. ${ }^{5}$ In addition, the website owners can control what they allow the people to see and analyze how consumers behave on the website.

3 Jonathan, William, and Sri Lestari. "Sistem informasi UKM berbasis website pada desa Sumber Jaya." Jurnal Teknologi Informasi dan Bisnis Pengabdian Masyarakat Darmajaya 1.1 (2015): 1-16.

4 Pratomo, Adi, et al. "Optimasi E-Commerce Dengan Penerapan Teknik SEO (Search Engine Optimization) Untuk Meningkatkan Penjualan Pada UKM Nida Sasirangan." Jurnal IMPACT: Implementation and Action 1.1 (2019): 37-47.

5 Sudaryanto, Ragimun, and Rahma Rina Wijayanti. "Strategi pemberdayaan UMKM menghadapi pasar bebas Asean." Pusat Kebijakan Ekonomi Makro. Badan Kebijakan Fiskal. Kementerian Keuangan, Jakarta (2013). 
The MSME market coverage will also be more global because the websites can reach a broader market not only the domestic market but also the overseas market.

\section{Method}

The method used in this community service activity is a service learning approach. ${ }^{6}$ It aims to overcome the problems faced by the target partners and to meet the practical needs of the assisted communities through finding solutions to those problems. It consists of three stages, namely the preparation stage, the service stage and the reflection stage. The subjects of this service activity are MSME actors in Buah Batu District, Bandung and IT staff in the area of Buah Batu District, Bandung.

The preparation stage was carried out by the team through FGD (Focus Group Discussion) activities with representatives of MSME actors and representatives of the staff of Buah Batu District, as well as pre-research (initial identification) for mapping the community potential.

The next stage is the service stage. At this stage, the team provides assistance to target partners through creative digital marketing workshops and assistance in packaging and labeling. This activity aims to provide information to MSME actors in Buahbatu District who have not implemented creative digital marketing strategies on their businesses, followed by the introduction of several examples of good and standardized product designs (packaging and labeling). In addition, the team also provides networking management assistance for IT staff and creates MSME websites. At this stage, all audiences (target partners) are also given a question and answer session about problems and obstacles or other practical questions for implementing creative digital marketing strategies in MSMEs.

The last stage is the reflection stage, the team evaluates the results of assistance programs from the changes that occur in the assisted MSMEs, including the increasing competence of target partners, the changing in packaging design, and the optimized usage of digital marketing strategies.

${ }^{6}$ Muh Barid Nizarudin Wajdi et al., "Pendampingan Redesign Pembelajaran Masa Pandemi Covid19 Bagi Tenaga Pendidik Di Lembaga Pendidikan Berbasis Pesantren Di Jawa Timur," Engagement: Jurnal Pengabdian Kepada Masyarakat 4, no. 1 (2020): 266-277; Irene Nusanti, "'Strategi Service Learning Sebuah Kajian Untuk Mengembangkan Kegiatan Pembelajaran," Jurnal Pendidikan dan Kebudayaan 20, no. 2 (2014): 251-260, http://up.openjournaltheme.com/jurnaldikbud/ojs-3.1.24/index.php/jpnk/article/view/142; Kathy L Guthrie and Holly McCracken, "Teaching and Learning Social Justice through Online Service-Learning Courses," The International Review of Research in Open and Distributed Learning 11, no. 3 SE-Research Articles (October 15, 2010): 78-94, http://www.irrodl.org/index.php/irrodl/article/view/894. 


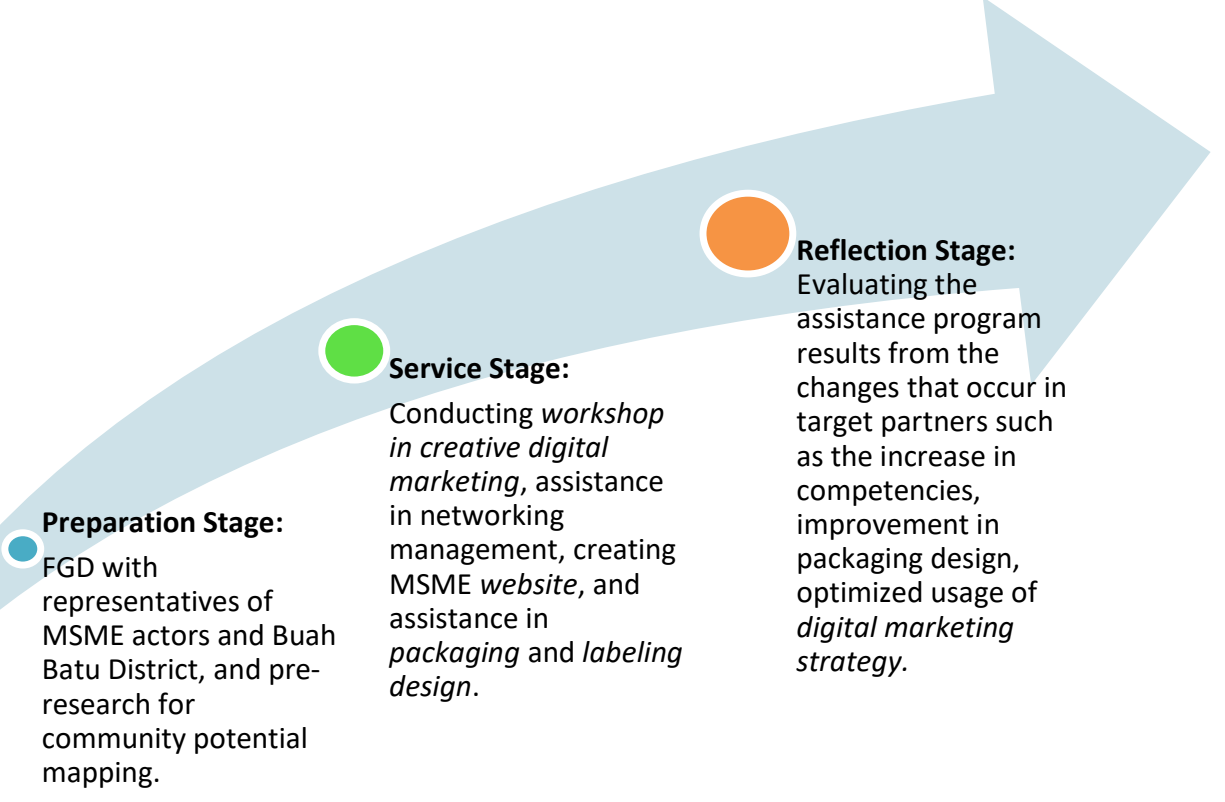

Figure 2. The Stages of Community Service Activities

\section{Results}

\section{Preparation of MSME Assistance Programs to Improve Product Competitive Advantages}

The preparation stage for assisting MSME actors begins with the data collection process through focus group discussion (FGD) activities. ${ }^{7}$ The data is needed to obtain an overview of the current conditions (existing) through interviews and a Focus Group Discussion (FGD) with MSME actors and the head of the relevant divisions in Buah Batu District. The team was able to obtain the following data: (a) profiles of MSMEs and target communities; (b) real problems faced by each target community; (c) mapping the potential of MSMEs; (d) functionality features, which are the requirements and specifications needed for data management in Buahbatu District website and complete and integrated community profiles.

MSME actors in Buah Batu District have already had insight and expertise in marketing their products. However, those marketing ability has not yet been fully implemented in term of creative digital marketing, such as the use of perfunctory packaging designs, unstandardized labeling, and the lack of use of digital media in marketing activities. In addition, the inadequate competence of IT employees in Buah Batu District regarding network maintenance.

7 Harinie, Luluk Tri, and Alexandra Hukom. "Pendampingan dalam Memasarkan Produk Hasil Usaha UKM melalui Penggunaan Media Sosial di Kabupaten Gunung Mas Kalimantan Tengah." Engagement: Jurnal Pengabdian Kepada Masyarakat 4.1 (2020): 51-59. 
Referring to the situation and problems faced by target partners, the community service team proposes several alternative solutions that are expected to be useful for Buah Batu District in particular and the entire community in Buah Batu District in general. The alternative solutions are as follows: (1) Providing creative digital marketing workshops for MSMEs in Buah Batu District, Bandung. (2) Providing product design and packaging workshops for superior products in Buah Batu District, Bandung. (3) Providing network management assistance for IT staff in Buah Batu District and build a website as a promotional medium for MSME superior products in Buah Batu District.

\section{Service Stage: Assistance Programs for MSMEs in Improving the Product's Competitive Advantages}

There are two groups of target partners in this service activity. The first group is MSME actors who are given creative digital marketing strategy assistance and promotions for MSMEs as well as assistance in packaging designs. The second group is IT staff in Buah Batu District who are provided with internetworking and network management assistance.

To increase the competitive advantage of superior products in Buah Batu District, the community service team started the assistance programs by holding a creative digital marketing workshop. The workshop explained marketing strategies for MSME actors in the Buahbatu District area that could help them to increase their product's competitive advantages and to expand their market coverage. Through the assistance and digital marketing strategy workshops, target partners can produce products that are able to compete with other products so that it has a higher selling value and the newly-created social media and marketplace account for MSMEs can be used as digital promotion media. Besides that, the team also conducted a product design workshop (packaging and labeling). With the improvement in the quality of product design and packaging, MSMEs in Buah Batu District have attractive values in their packaging and also meet the industrial packaging standards which make them capable to compete with competing products.

The results of this workshops are as follows: increasing the knowledge of MSME actors regarding digital marketing and promotions that utilize digital media such as social media marketing, website marketing, email marketing, blogs, marketplaces, digital advertising, etc. MSME actors are also directed to implement several digital marketing strategies, namely social media marketing and marketplaces (Tokopedia and Shopee). 

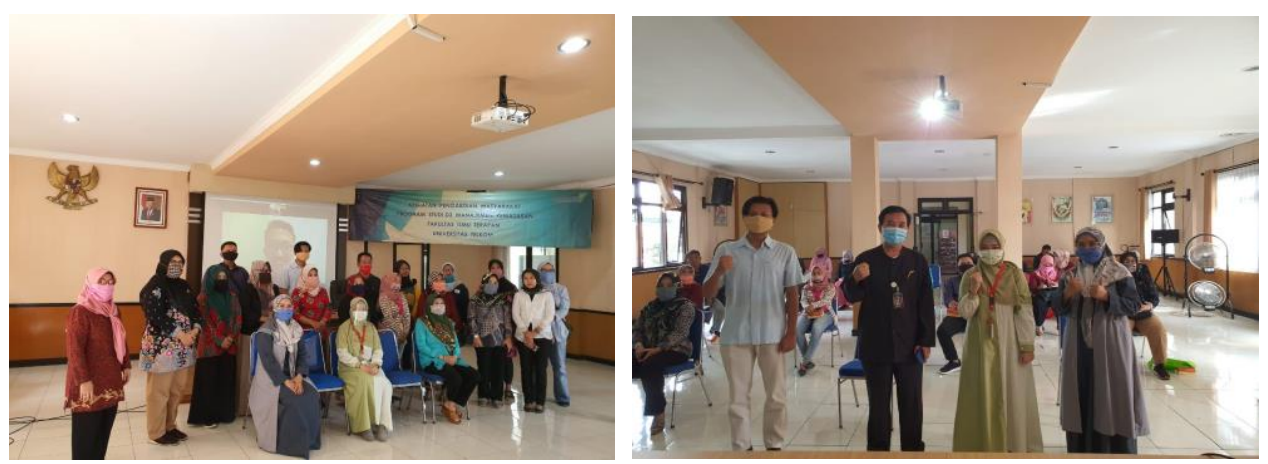

Figure 3. Digital Marketing Strategy Workshop for MSMEs

The other achievement is the improvement of MSME actors' knowledge regarding packaging designs for their products. They have a better understanding of the criteria for good packaging and the components that need to be included in product packaging. The team also provides reviews and input on the packaging of MSME products. The team also provided examples of packaging designs for several MSMEs as presented in the following images.
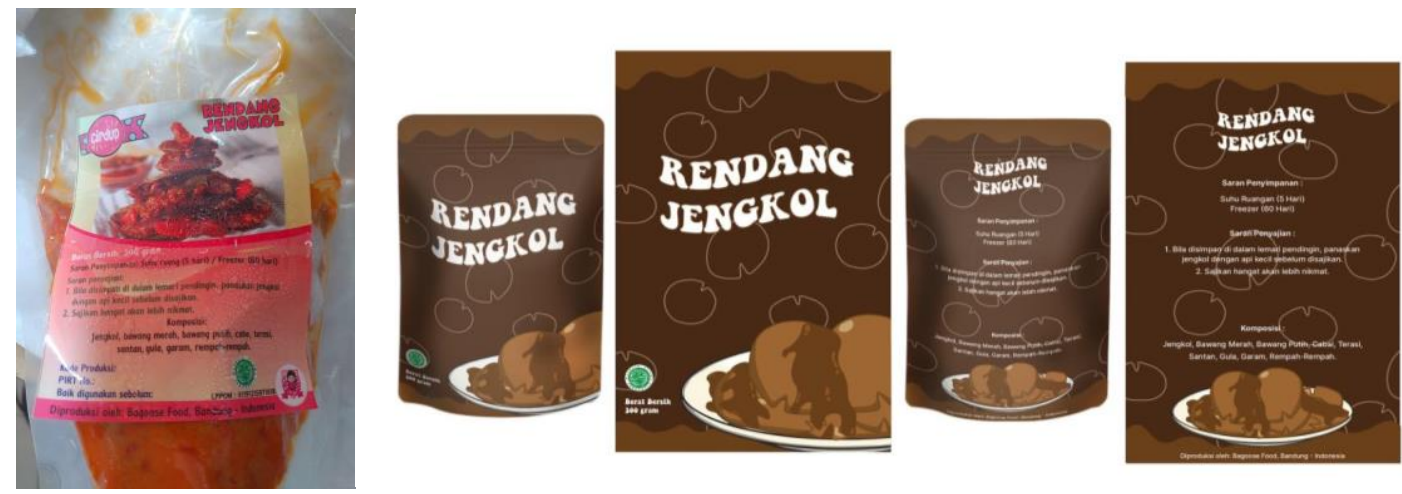

Figure 4. Packaging Design for Rendang Jengkol Before and After the Assistance Programs
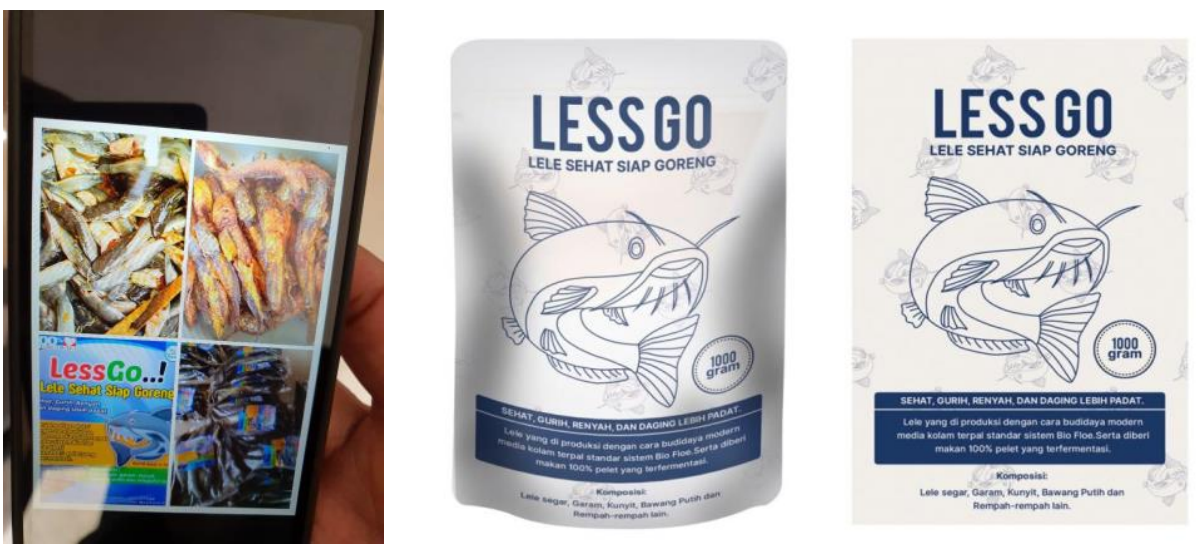

Figure 5. Packaging Design for Ready-to-Cook Catfish Product Before and After the Assistance Programs 
The community service team also carried out mentoring activities in the form of workshops, counseling, and socialization of the use of technology. The team provided network management assistance for IT staff in Buah Batu District to increase their competencies in reliable network management. The implementation of network management assistance included the following steps. ${ }^{8}$ (1) Analytical activities are carried out to describe each stage (process) of the business which would be evaluated to get detailed descriptions of the current condition, to identify the current problems, and as a benchmark for identifying the features and functionality of the website; (2) Planning activities for designing databases, functionality modeling, and designing interfaces; (3) Implementation, trial phase, and website documentation. ${ }^{9}$ At this stage, the team started coding the program based on the previously made design to build a website; (4) Conducting tests on the applications to ensure its functionality and validity; (5) Documentation of the website as the website user's manuals; (6) Socializing the operation of the application. ${ }^{10}$ The goal is to train and ensure all users are capable to operate the application and website. Furthermore, the team also conducted socialization for other related parties. By updating and integrating the website of the Buah Batu District makes it easier for its users.

Furthermore, the achievements of this community service are the improvement of IT staff's competencies regarding internetworking development, namely designing a reliable network, integrating old and new systems and the computer network maintenance processes in Buah Batu District.
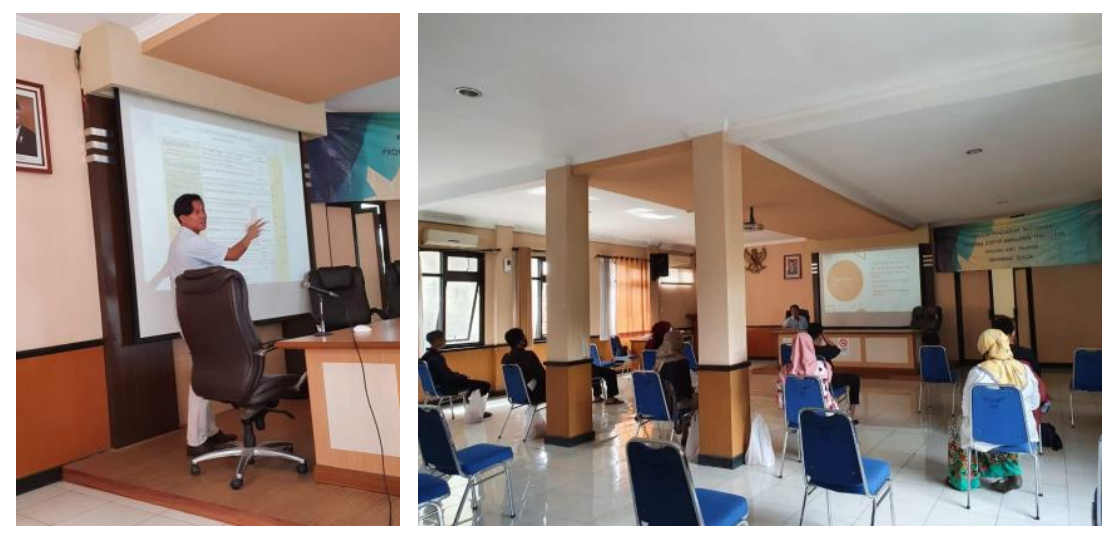

Figure 6. Internetworking Assistance for IT Staff

8 Darnis, Febriyanti, and Rezania Agramanisti Azdy. "Pemanfaatan Media Informasi Website Promosi (e-Commerce) sebagai Upaya Peningkatan Pendapatan UMKM Desa Pedado." SINDIMAS 1.1 (2019): 275-278.

${ }_{9}^{9}$ Wahyudi, Setyo Tri, et al. "Optimalisasi Website kedirimenjual. com untuk Meningkatkan Brand Awareness Produk UMKM Kabupaten Kediri Melalui Digital Marketing." Jurnal Pengabdian dan Pengembangan Masyarakat 2.2 (2019): 313-325.

10 Purwana, Dedi, R. Rahmi, and Shandy Aditya. "Pemanfaatan Digital Marketing Bagi Usaha Mikro, Kecil, Dan Menengah (UMKM) Di Kelurahan Malaka Sari, Duren Sawit." Jurnal Pemberdayaan Masyarakat Madani (JPMM) 1.1 (2017): 1-17. 


\section{Reflection Stage of MSME Assistance Programs to Increase Product's Competitive Advantages}

After the community service activities are carried out, the comparison between the problems and the overall results are described in Table 1 below.

Table 1. Reflection of MSMEs and IT Staff Assistance Results

\begin{tabular}{llll}
\hline No. & \multicolumn{1}{c}{ Before Assistance } & \multicolumn{1}{c}{ During Assistance } & Evaluation of Assistance \\
\hline $\begin{array}{l}\text { Having no expertise in } \\
\text { MSME products digital } \\
\text { marketing. }\end{array}$ & $\begin{array}{l}\text { Given assistance to improve } \\
\text { knowledge and expertise in } \\
\text { digital marketing. }\end{array}$ & $\begin{array}{l}\text { 96,4\% of the participants } \\
\text { understand and gain } \\
\text { expertise in digital } \\
\text { marketing techniques. }\end{array}$ \\
\hline $\begin{array}{l}\text { Inadequate product } \\
\text { designs (packaging dan } \\
\text { labeling). }\end{array}$ & $\begin{array}{l}\text { Given assistance about product } \\
\text { design so the product's } \\
\text { packaging and labeling meet the } \\
\text { industrial standards. }\end{array}$ & $\begin{array}{l}96,4 \% \text { of the participants } \\
\text { understand and gain } \\
\text { expertise in creating } \\
\text { adequate product design. }\end{array}$ \\
\hline $\begin{array}{l}\text { IT staff are lack of } \\
\text { capabilities to solve } \\
\text { network management } \\
\text { problems. }\end{array}$ & $\begin{array}{l}\text { Given assistance in } \\
\text { internetworking (network } \\
\text { management) for IT staff. }\end{array}$ & $\begin{array}{l}70 \% \text { of the participants } \\
\text { have practical skills in } \\
\text { network management. }\end{array}$ \\
\hline
\end{tabular}

The MSME actors in Buah Batu District have experienced a change in their business methods. Initially, they used conventional marketing techniques but after the assistance programs, they began to implement creative digital marketing strategies that were more adaptive to the rapid technology development. Then from the aspect of product design, MSME actors upgraded their packaging designs to be more attractive and meet the industrial standards. The assistance in internetworking resulted in IT staff who are more capable of managing networks in Buah Batu District.

\section{Discussion}

MSME actors have had sufficient competence and ability in business management and product marketing. But in general, the MSME actors face difficulties in implementing digital marketing techniques and creatively designing their products. The IT staff also have good competence in their fields, but the IT network management between each office under the auspices of Buah Batu district is still constrained.

After implementing the assistance programs for target partners, there were several significant changes in products sales in each MSME. It happened because these MSMEs have implemented creative digital marketing strategies by promoting their 
products via social media, websites, and e-commerce. ${ }^{11}$ Knowledge is a major concern for successfully implementing digital marketing, such as the understanding of using the internet for product communication, knowing the target market of their businesses, and using digital marketing as one of the tools to meet market needs. This knowledge cannot be obtained only from word of mouth, but also requires the initiative and willingness of MSME actors to follow the latest world issues so that it can be spread in various circles of society. The MSME actors also need to continuously upgrade their knowledge of the current market situation, market demand, and trends in communities. ${ }^{12}$ With the development of technology, information can be easily obtained by using the internet. ${ }^{13}$ MSME entrepreneurs must realize that, apart from the many opportunities to develop their businesses, the competition is also getting tighter. Therefore, it is crucial for a businessman to continuously seek, learn, and implement his business strategy. It is also important to get support from the government and related agencies to assist MSME actors in understanding ICT adoption for their businesses as a form of implementing creative digital marketing strategies.

Furthermore, the increase in sales occurred after the workshop on proper packaging for MSME's products. There are various reasons why many MSME products in Buah Batu District have difficulties competing with similar products. This is caused by the many obstacles faced by MSMEs. ${ }^{14}$ One of them is the lack of information about the importance of packaging in marketing their products. Most of the assistance participants (MSME actors) underestimated the role of packaging. Many of them did not pay attention to product packaging, thus making the product lost its commercial value in the eyes of consumers. As the result, many MSME products were not selling well in the market. This situation is exacerbated by the absence of business units that can handle small batch packaging. So, if MSME actors wanted to make their product packaging more attractive and sellable, they did not know what to do. ${ }^{15}$ Actually, innovative and creative product packaging can increase MSME's profit. ${ }^{16}$ Based on the results of previous research,

11 Afifah, Aisyah Nur, and Mukhamad Najib. "Digital Marketing Adoption And The Influences Towards Business Successes Of Msmes Creative Sector In Indonesia And Malaysia." Jurnal Aplikasi Manajemen 16.3 (2018): 377-386.

12 Dora, Yenny Maya, and Mohd Haizam Saudi. "The Role of Digital Marketing With Creativity and Innovation for Sustainable MSMEs." PalArch's Journal of Archaeology of Egypt/Egyptology 17.10 (2020): 2902-2913.

13 Hapsoro, Bayu Bagas, Palupiningdyah Palupiningdyah, and Achmad Slamet. "Peran Digital Marketing sebagai Upaya Peningkatan Omset Penjualan Bagi Klaster UMKM di Kota Semarang." Jurnal Abdimas 23.2 (2019): 117-120.

14 Rizkavirwan, Darfi, and Luisa Erica. "Improving the Persuasion Function in Packaging Design Through Redesigning Ready to Use Plastic Pouch Food Packaging for Micro Small Medium Enterprise Businesses." International Conference of Innovation in Media and Visual Design (IMDES 2020) Atlantis Press (2020): 53-59.

15 Barovih, Guntoro, and Nurussama Nurussama. "Penerapan E-Commerce dan Inovasi Kemasan untuk Produsen Pia Kota Palembang." Prosiding Seminar Nasional Hasil Litbangyasa Industri II 1.1 (2018): 118-128.

${ }^{16}$ Erlyana, Yana. "The Effect of Packaging Design on the Improvement of MSME Brand Value Using 
industry practitioners, especially MSMEs need to consider the increase of brand value through packaging design. The comparison between the analysis results from the first test (pre-test), where the products were using ordinary plastic packaging without being visually designed, and the analysis results from the second test (post-test) where the same products were given a well-designed packaging with aesthetics and functionality values, shows significantly different results in terms of value. The first test only showed the aesthetic aspects that affect the brand value of the product while the second test showed that both aesthetic and functional aspects affect the product brand value partially or simultaneously.

Internetworking merupakan sebuah proses pendampingan awal untuk operator jaringan. Pendampingan ini memberikan pengetahuan dasar di bidang jaringan, topologi, Ethernet, point-to-point dan point-to-multipoint, serta menangani OSI, TCP IP, bridge, switch, router, dan manajemen alamat IP secara lebih rinci. Pendampingan internetworking yang telah dilaksanakan di Kecamatan Buah Batu diharapkan akan memberikan pengetahuan dasar tentang jaringan kepada para staf IT Kecamatan Buah Batu. Adapun tujuan diberikan pendampingan internetworking tersebut kepada para staf IT di Kecamatan Buah Batu adalah agar mereka mampu memahami konsep dasar dari jaringan, kemudian dapat memahami konsep dan implementasi OSI dan TCP/IP, mampu menghitung IP Subnet dan manajemen jaringan berbasis IP, serta mampu memahami komponen jaringan seperti Bridge, Switch dan Router. ${ }^{17}$ Temuan dari riset terdahulu menunjukkan bahwa interface yang digunakan tidak secara signifikan mempengaruhi kemampuan pengguna untuk menemukan informasi di Internet. Namun, pendampingan internetworking yang lebih lama memang menghasilkan pencarian yang lebih baik, setidaknya pada setiap awalannya. Keyakinan pengguna dalam menggunakan berbagai alat tergantung kepada variasi untuk setiap sumber daya. Tindak lanjut penilaian menunjukkan bahwa perbedaan sikap pengguna antara kelompok menurun dari waktu ke waktu.

Internetworking was an initial assisting process for network operators. This assistance provided detailed basic knowledge in networking, topology, Ethernet, pointto-point, and point-to-multipoint, and handles OSI, TCP IP, bridges, switches, routers, and IP address management. The internetworking assistance that has been carried out in Buah Batu District was expected to provide basic networking knowledge to IT staff in Buah Batu District. The purpose of providing internetworking assistance to IT staff in Buah Batu District was to improve their understanding of basic concepts of the network, give a better understanding of the concept and implementation of OSI and TCP/IP, train

the Pre-test and Post-tests Methods". International Conference of Innovation in Media and Visual Design (IMDES 2020) Atlantis Press (2020): 261-267.

17 Senkevitch, Judith, and Dietmar Wolfram. "Internetworking an urban community: A longitudinal study of approaches to introducing adult new users to electronic information resources." Library \& information science research 19.3 (1997): 249-264. 
their skills in calculating IP Subnets and IP-based network management, and enhance their understanding of network components such as Bridges, Switches and Routers. 1The findings from previous research showed that the interface used did not significantly affect the user's ability to find information from the Internet. However, longer internetworking assistance resulted in better searches, at least initially. The user confidence in using various tools depends on the variations of each resource. The followup assessments showed that differences in user attitudes among groups decreased over time.

\section{Conclusion}

The assistance programs for MSME practitioners in Buah Batu District through a service-learning approach successfully provide innovations for their superior products so that they can continue to grow and develop. These assistance activities added skills for MSME actors in creative product marketing with the support of digital or online marketing such as WhatsApp, Facebook, Instagram, marketplaces, and others. The target partners have also been able to produce attractive product designs (packaging and labeling) that meet industrial standards. Apart from implementing the tri dharma of higher education, this community service also helped the government programs in encouraging MSME actors to be able to compete in the global market so they can prosper the surrounding communities. Target partners have also been given assistance and workshops in advanced network and website management.

\section{Declaration}

These community service activities were fully supported by the Directorate of Research and Community Service of Telkom University in 2020.

\section{References}

Afifah, Aisyah Nur, and Mukhamad Najib. "Digital Marketing Adoption And The Influences Towards Business Successes of Msmes Creative Sector In Indonesia And Malaysia." Jurnal Aplikasi Manajemen 16.3 (2018): 377-386.

Barovih, Guntoro, and Nurussama Nurussama. "Penerapan E-Commerce dan Inovasi Kemasan untuk Produsen Pia Kota Palembang." Prosiding Seminar Nasional Hasil Litbangyasa Industri II 1.1 (2018): 118-128.

Darnis, Febriyanti, and Rezania Agramanisti Azdy. "Pemanfaatan Media Informasi Website Promosi (e-Commerce) sebagai Upaya Peningkatan Pendapatan UMKM Desa Pedado." SINDIMAS 1.1 (2019): 275-278.

Dora, Yenny Maya, and Mohd Haizam Saudi. "The Role of Digital Marketing With 
Creativity and Innovation for Sustainable MSMEs." PalArch's Journal of Archaeology of Egypt/Egyptology 17.10 (2020): 2902-2913.

Erlyana, Yana. "The Effect of Packaging Design on the Improvement of MSME Brand Value Using the Pre-test and Post-tests Methods". International Conference of Innovation in Media and Visual Design (IMDES 2020) Atlantis Press (2020): 261-267.

Guthrie, Kathy L, and Holly McCracken. "Teaching and Learning Social Justice through Online Service-Learning Courses." The International Review of Research in Open and Distributed Learning 11, no. 3 SE-Research Articles (October 15, 2010): 7894. http://www.irrodl.org/index.php/irrodl/article/view/894.

Hapsoro, Bayu Bagas, Palupiningdyah Palupiningdyah, and Achmad Slamet. "Peran Digital Marketing sebagai Upaya Peningkatan Omset Penjualan Bagi Klaster UMKM di Kota Semarang." Jurnal Abdimas 23.2 (2019): 117-120.

Harinie, Luluk Tri, and Alexandra Hukom. "Pendampingan dalam Memasarkan Produk Hasil Usaha UKM melalui Penggunaan Media Sosial di Kabupaten Gunung Mas Kalimantan Tengah." Engagement: Jurnal Pengabdian Kepada Masyarakat 4.1 (2020): 51-59.

Jonathan, William, and Sri Lestari. "Sistem informasi UKM berbasis website pada desa Sumber Jaya." Jurnal Teknologi Informasi dan Bisnis Pengabdian Masyarakat Darmajaya 1.1 (2015): 1-16.

Nusanti, Irene. “"Strategi Service Learning Sebuah Kajian Untuk Mengembangkan Kegiatan Pembelajaran." Jurnal Pendidikan dan Kebudayaan 20, no. 2 (2014): 251$260 . \quad$ http://up.openjournaltheme.com/jurnaldikbud/ojs-3.1.24/index.php/jpnk/article/view/142.

Pratomo, Adi, et al. "Optimasi E-Commerce Dengan Penerapan Teknik SEO (Search Engine Optimization) Untuk Meningkatkan Penjualan Pada UKM Nida Sasirangan." Jurnal IMPACT: Implementation and Action 1.1 (2019): 37-47.

Purwana, Dedi, R. Rahmi, and Shandy Aditya. "Pemanfaatan Digital Marketing Bagi Usaha Mikro, Kecil, Dan Menengah (UMKM) Di Kelurahan Malaka Sari, Duren Sawit." Jurnal Pemberdayaan Masyarakat Madani (JPMM) 1.1 (2017): 1-17.

Rizkavirwan, Darfi, and Luisa Erica. "Improving the Persuasion Function in Packaging Design Through Redesigning Ready to Use Plastic Pouch Food Packaging for Micro Small Medium Enterprise Businesses." International Conference of Innovation in Media and Visual Design (IMDES 2020) Atlantis Press (2020): 53-59.

Senkevitch, Judith, and Dietmar Wolfram. "Internetworking an urban community: A longitudinal study of approaches to introducing adult new users to electronic information resources." Library \& information science research 19.3 (1997): 249264.

Sudaryanto, Ragimun, and Rahma Rina Wijayanti. "Strategi pemberdayaan UMKM menghadapi pasar bebas Asean." Pusat Kebijakan Ekonomi Makro. Badan Kebijakan Fiskal. Kementerian Keuangan, Jakarta (2013).

Vernia, Dellia Mila. "Peranan Pendidikan dan Pelatihan Media Sosial dalam Pemasaran 
Online untuk Meningkatkan Daya Saing Usaha Mikro Kecil Menengah (UMKM)." Lectura: Jurnal Pendidikan 8.2 (2017).

Wahyudi, Setyo Tri, et al. "Optimalisasi Website kedirimenjual. com untuk Meningkatkan Brand Awareness Produk UMKM Kabupaten Kediri Melalui Digital Marketing." Jurnal Pengabdian dan Pengembangan Masyarakat 2.2 (2019): 313325.

Wajdi, Muh Barid Nizarudin, Burhanuddin Ubaidillah, Sri Mulyani, Khoirul Anwar, Lailatul Istiqomah, Fauziyah Rahmawati, Sholihatul Atik Hikmawati, Diah Retno Ningsih, and Hasan Syaiful Rizal. "Pendampingan Redesign Pembelajaran Masa Pandemi Covid-19 Bagi Tenaga Pendidik Di Lembaga Pendidikan Berbasis Pesantren Di Jawa Timur." Engagement: Jurnal Pengabdian Kepada Masyarakat 4, no. 1 (2020): 266-277.

Zain, Nuryetty, and Susan Febriantina. "Sosialisasi Kewirausahaan dan Pendidikan Anak; Antara Bisnis On Line dan Mengasuh di Era Digital." Jurnal Pemberdayaan Masyarakat Madani (JPMM) 1.2 (2017): 267-279. 